\title{
Animal model and therapeutic prospects for left ventricular hypertrophy and associated renal complication
}

Ashfaq Ahmad ${ }^{1,2,}$, Zainab Riaz ${ }^{3 *}$, Munavvar Abdul Sattar ${ }^{1}$, Safia Akhtar Khan ${ }^{1}$, Edward James

$\mathrm{John}^{4}$, Sumbal Arshad ${ }^{3}$, Syed Tahir Abbas Shah ${ }^{3}$, Muhammad Arshad Rafiq1,3,\#, Maleeha Azam $^{3, \#, \&, ~ R a h e e l ~ Q a m a r 1,5, \# ~}$

${ }^{1}$ School of Pharmaceutical Sciences, Universiti Sains Malaysia, Penang, Malaysia

${ }^{2}$ Department of Pharmacology and Toxicology, Virginia Commonwealth University, Richmond, Virginia, USA;

${ }^{3}$ Translational Genomics Laboratory, Department of Biosciences, COMSATS University Islamabad, Pakistan

${ }^{4}$ Department of Physiology, University College Cork, Cork, Ireland;

${ }^{5}$ Pakistan Academy of Sciences, Islamabad, Pakistan

*shared first position

\#Shared last position

${ }^{\&}$ Address for correspondence

Maleeha Azam, Translational Genomics Laboratory, Department of Biosciences, COMSATS University Islamabad, Pakistan, Tarlai Kalan, Islamabad-45550, Pakistan. Phone: (92)-(51)9235033; Fax: (92)-(51)-9247008; email: malihazam@gmail.com 


\begin{abstract}
Cardiac and renal dysfunction often co-occur and considerably worsen the prognosis leading to difficulty in therapy in left ventricular hypertrophy (LVH). The aim of this study was to elucidate changes in expression of human ortholog genes of hypertension, vascular and cardiac remodeling and hypertensive nephropathy phenotypes under normal, disease and gasotransmitter, $\mathrm{H}_{2} \mathrm{~S}$ (hydrogen sulphide) and $\mathrm{NO}$ (nitric oxide) and combined $\left(\mathrm{H}_{2} \mathrm{~S}+\mathrm{NO}\right)$, treatment of rat myocardium and renal tissues. LVH rat models were generated and were treated with $\mathrm{H}_{2} \mathrm{~S}$ and NO. Relative gene expression was quantified. Heart and renal physical indices were significantly modified under individual as well as combined $\mathrm{H}_{2} \mathrm{~S}+\mathrm{NO}$ treatment in control and $\mathrm{LVH}$ rats. Expression analysis revealed, hypertension, vascular remodeling genes $A C E, T N F \alpha$ and $I G F 1$, mRNAs to be significantly increased $(\mathrm{P}<0.05)$ in myocardia and kidneys of LVH rats, while individual and combined $\mathrm{H}_{2} \mathrm{~S}+\mathrm{NO}$ treatment reduced gene expression to normal/near to normal values. The cardiac remodeling genes $M Y H 7, T G F \beta, S M A D 4$ and $B R G 1$ expression were significantly up-regulated $(\mathrm{P}<0.05)$ in the myocardia of $\mathrm{LVH}$ and combined $\mathrm{H}_{2} \mathrm{~S}+\mathrm{NO}$ treatment, which recovered the normal/near to normal expression more effectively as compared to individual treatments. Interestingly, individual as well as combined $\mathrm{H}_{2} \mathrm{~S}$ and $\mathrm{NO}$ treatment significantly decreased PKDI expression in renal tissue, which was significantly up-regulated in LVH rats $(\mathrm{P}<0.05)$. The reduction in hemodynamic parameters and cardiac indices as well as alteration in gene expression on treatment in LVH rat model indicates important therapeutic potential of combined treatment with $\mathrm{H}_{2} \mathrm{~S}+\mathrm{NO}$ gasotransmitters in hypertension and cardiac hypertrophy associated with renal complications.
\end{abstract}

Keywords: Left ventricular hypertrophy; gasotansmitters; therapeutics; cytoprotection 


\section{Introduction}

Left ventricular hypertrophy (LVH) develops as an adaptive response to increased hypertension induced cardiac workload and volumetric overload. The hypertrophied myocardium adversely affects cardiac function and is a major factor contributing to heart failure [1]. Cardiac and renal dysfunction often co-occur and considerably worsen the prognosis; renal dysfunction can be causative and/or a complication of cardiovascular disease [1]. Physiological cardio-renal interactions can be explained in terms of systemic hemodynamics and renal-body fluid system for blood pressure control [2]. Activation of the sympathetic nervous system and reninangiotensin system (RAS) in response to decreased cardiac output causes volume expansion and restores renal blood flow [3]. Renal control of blood pressure has a near infinite feedback gain principle such that renal failure, as a consequence of heart failure, causes sodium and water retention, which further exacerbates the cardiac failure [2]. Hypertension induced LVH is associated with vascular remodeling, mediated by vasoactive molecules and endothelial dysfunction as prominent pathological features [4]. Moreover, gene expression changes in the myocardium following stimuli such as pressure overload results in expression of alternate isoform of sarcomeric proteins, which is a major factor contributing to cardiac remodeling and hypertrophied growth of the adult heart muscle [5].

The gasotransmitters hydrogen sulphide $\left(\mathrm{H}_{2} \mathrm{~S}\right)$ and nitric oxide (NO) are increasingly being studied for their therapeutic potential in treating cardiovascular disease [6,7]. Endogenously $\mathrm{H}_{2} \mathrm{~S}$ is produced by pyridoxal-5'-phosphate (PLP)-dependent enzymes [8], while NO is generated by nitric oxide synthases [9]. Several studies have demonstrated the pivotal role of $\mathrm{H}_{2} \mathrm{~S}$ in protecting against cardiac hypertrophy by reducing oxidative stress [10], myocardial apoptosis [11], hypertrophy and collagen content [12] and down-regulation of angiotensin II levels [13]. The 
development of cardiac hypertrophy in mice lacking nitric oxide synthases [14] and the attenuation of LVH in hypertensive rats following treatment with L-arginine to improve NO production [15] highlights the therapeutic role of NO in ameliorating LVH. Recently, a hypothetical model proposed by Yong et al. [16] and Nagpure et al. [17] have shown the existence of interaction between $\mathrm{H}_{2} \mathrm{~S}$ and $\mathrm{NO}$, due to the production of intermediate HSNO (thionitrous acid) and $\mathrm{HNO}$ (nitroxyl) gases [16], the synergistic effect elicited by $\mathrm{H}_{2} \mathrm{~S}$, $\mathrm{NO}$ and these intermediate product is proposed to lead to cardio protection, maintenance of vascular tone and reduced oxidative stress. Recent studies have also shown that the pyridoxal-5'-phosphate (PLP)-dependent enzymes that produce $\mathrm{H}_{2} \mathrm{~S}$ are expressed in the kidney [18], where $\mathrm{H}_{2} \mathrm{~S}$ shows a protective role against chronic renal failure [19], renal ischemia/reperfusion injury [20] and control renal tubular and vascular function [21]. NO plays a significant role in regulating renal hemodynamics and tubular function [22] and, therefore, maintenance of arterial pressure and vascular volume [23]. This notion is further supported by the implication of NO deficiency in the progression of hypertension and renal diseases [24]. However, the effects of modulatory control of combined therapy with gasotransmitters $\mathrm{H}_{2} \mathrm{~S}$ and $\mathrm{NO}$, for the treatment of cardiovascular and renal disease remains largely unexplored.

In the present study we investigated the modulation of the expression of specific genes in response to individual and combined treatment of $\mathrm{H}_{2} \mathrm{~S}$ and $\mathrm{NO}$ gasotransmitters in the myocardium and renal tissue of control and LVH rat models. The studied genes are known to be involved in hypertension, vascular and cardiac remodeling and hypertensive nephropathy in human.

\section{Materials and Methods}

\section{Study approval}


Animal experimentation protocols used in this study were approved by the Animal Research and

Service Centre "ARASC" under the Animal Ethics Committee, Universiti Sains Malaysia “AECUSM" (approval number: 2012/76/364) and Ethic Review Board of the Department of Biosciences, COMSATS Institute of Information Technology, Islamabad, Pakistan.

\section{Experimental Animals}

Male Wistar-Kyoto (WKY) rats with body weight in the range of 180-200g were procured from ARASC and acclimatized for 5 days in the new environment with food and water available ad libitum. Isoprenaline $(5 \mathrm{mg} / \mathrm{kg} \mathrm{S} / \mathrm{C}$ every $72 \mathrm{hrs})$ was administered subcutaneously as 5 injections and caffeine $(62 \mathrm{mg} / \mathrm{L})$ was given in drinking water to the WKY rats for 14 days to induce $\mathrm{LVH}$ [25]. The $\mathrm{H}_{2} \mathrm{~S}$ donor NaHS $(56 \mu \mathrm{M} / \mathrm{kg})$ was administered exogenously in daily intraperitoneal injections for 5 weeks [26], beginning 3 weeks prior to isoprenaline and caffeine administration, while the control groups received saline injections in a similar manner. L-arginine $(1.25 \mathrm{~g} / \mathrm{L})$ was given in drinking water as NO donor for 5 weeks [27].

Seventy two rats were divided into two groups, one for the cardiovascular investigations and renal functional study in acute experiment and the other group for molecular expression studies of the myocardium and renal tissues. Both groups were further divided into 8 sub-groups: Control, LVH, Control- $\mathrm{H}_{2} \mathrm{~S}$ (NaHS treated control), Control-NO (L-arginine treated control), Control- $\mathrm{H}_{2} \mathrm{~S}+\mathrm{NO}$ (NaHS and L-arginine treated control), LVH- $\mathrm{H}_{2} \mathrm{~S}$ (NaHS treated LVH), LVH$\mathrm{NO}$ (L-arginine treated LVH) and $\mathrm{LVH}-\mathrm{H}_{2} \mathrm{~S}+\mathrm{NO}$ (NaHS and L-arginine treated LVH); both $\mathrm{H}_{2} \mathrm{~S}$ and NO were given separately to the same animal groups ( $\mathrm{n}=48$ i.e. 6 rats per group) for the acute studies and $n=24$ i.e. 3 rats per group for the molecular expression studies.

\section{$\mathrm{H}_{2} \mathrm{~S}$ and NO plasma concentration measurement}


At the end of the treatment period, tail vein blood sample was taken from each rat and subjected to centrifugation at $2000 \mathrm{x}$ g for 10 minutes [25]. Plasma $\mathrm{H}_{2} \mathrm{~S}$ concentration was measured using a standard procedure $[21,26]$. NO level in the plasma was measured using a laboratory kit (NJJC Bio Inc., Nanjing, China) by following the manufacturer's instructions.

\section{Acute experiment}

The acute experiment (on anesthetized non-behaving animals) was performed according to previously reported protocol [25]. The rats were made to fast overnight, by removing food from their cages the night before the experiment, and anaesthetized by intraperitoneally administering 60mg/kg pentobarbitone sodium (Nembutal; CEVA Sante Animale, Libourne, France). A cannula was introduced into the trachea to facilitate ventilation. Following this the right carotid artery was cannulated (PP50, Portex, Kent, UK) and the cannula was connected to a pressure transducer (model P23 ID Gould, Statham Instruments, UK), which was in turn connected to a data acquisition system (PowerLab®, ADInstrument, Australia) to continuously monitor mean arterial pressure (MAP). The left jugular vein was cannulated (PP50, Portex, Kent, UK) to allow infusion of maintenance doses of anesthesia and saline as required. A mid-line abdominal incision exposed the left kidney, which was covered with saline soaked pads to prevent drying. A cannula (PP50, Portex, Kent, UK) was inserted into the iliac artery and attached to another fluid filled pressure transducer connected to the PowerLab system to measure iliac mean blood pressure. A laser Doppler flow probe (AD Instruments, Australia), positioned on the outermost layer of the left kidney cortex was used to record the renal cortical blood perfusion (RCBP). The MAP and RCBP were measured continuously for an hour before the rats were euthanized with an overdose of anesthetic and the hearts were harvested post-mortem, dried and weighed for heart and left ventricle (LV) indices to observe the induction of LVH and how treatment effects 
the regression of LVH. Internal diameter of the LV chamber and myocardium thickness were measured using vernier caliper according to previously reported protocol [28]. Pulse wave velocity (PWV) was measured by taking the propagation time of the pulse wave from Power Lab data and propagation distance was measured manually by putting a thread from the insertion point of the carotid artery cannula to that of the iliac artery cannula [29].

RNA extraction and expression analysis in myocardia and renal tissues of control, LVH,

\section{$\mathrm{H}_{2} \mathrm{~S}$ and NO treated rats}

Target tissues were extracted, disrupted and homogenized as previously described [30]. Briefly, following cervical dislocation, heart muscle and renal cortex were harvested and preserved in RNAlater solution (Ambion, Life Technologies Corporation, Carlsbad, CA) at $4^{\circ} \mathrm{C}$. RNAZap (Ambion, Life Technologies Corporation, Carlsbad, CA) solution was used to wash all equipment in order to maintain RNA integrity and prevent contamination. Total RNA was extracted using TRIzole reagent (Ambion, Life technologies, Carlsbad, CA) following the manufacturer's guidelines; after consecutive homogenization, washing and elution, total RNA was extracted and quantified for yield and purity using a microplate reader (Bio Tek Instrument. Inc., Winooski, VT). Total RNA was converted to cDNA using High-Capacity RNA-to-cDNA Kit (Applied Biosystems, Foster City, CA) according to the manufacturer's protocol using a StepOne Plus real-time polymerase chain reaction (RT-PCR) (Applied Biosystems, Foster City, CA). Relative gene expression of hypertension and vascular remodeling genes; angiotensin I converting enzyme (ACE; NM_012544.1), prostacyclin synthase (PTGIS; NM_031557.2), regulator of G protein signaling 5 (RGS5; NM_019341.1), tumor necrosis factor $\alpha$ (TNF $\alpha$; NM_012675.3), insulin-like growth factor 1 (IGF1; NM_001082478.1), were analyzed in heart and renal tissues, while cardiac remodeling genes; transforming growth factor $\beta 1$ (TGFß1; 
NM_021578.2), myosin heavy chain 7 (MYH7; NM_017240.2), brahma-related gene 1 (BRG1;

NM_134368.1), SMAD family member 4 (SMAD4; NM_019275.3), were studied in the cardiac tissues (Table 1). To determine the effect of $\mathrm{H}_{2} \mathrm{~S}$, NO and $\mathrm{H}_{2} \mathrm{~S}+\mathrm{NO}$ treatment on renal complication in LVH rats, expression of polycystic kidney disease gene; polycystic kidney disease 1 (PKD1; NM_001106352.1) was determined in renal tissue (Table 1), while glyceraldehyde 3-phosphate dehydrogenase (GAPDH; NM_017008.4) was used as the housekeeping gene internal control. Primers for RT-PCR were designed using an online primerdesigning tool (https://eu.idtdna.com/site at Integrated DNA Technologies, San Diego, CA ). RTPCR reactions were performed on RNA extracted from 3 animals each from the 8 groups (Control, LVH, Control- $\mathrm{H}_{2} \mathrm{~S}$, Control-NO, Control- $\mathrm{H}_{2} \mathrm{~S}+\mathrm{NO}$, LVH-H $\mathrm{H}_{2} \mathrm{~S}, \mathrm{LVH}-\mathrm{NO}$ and LVH$\mathrm{H}_{2} \mathrm{~S}+\mathrm{NO}$ ) and each heart and kidney sample was further analyzed in triplicate using maxima SYBR Green/ROX qPCR Kit (Thermo Scientific, Waltham, MA) according to the manufacturer's instructions on the AB1 StepOne RT-PCR system (Ambion, Foster City, CA). Relative quantification of target gene along with internal control was calculated using the comparative cycle threshold method $\left(2^{-\Delta \Delta C T}\right)$.

Table 1. Orthologous genes, \% identity of protein (Ensembl 2016) and cellular function

\begin{tabular}{|c|c|c|c|c|}
\hline \multirow{2}{*}{ Classification } & \multicolumn{2}{|c|}{ Orthologs } & \multirow{2}{*}{$\begin{array}{l}\text { Protein \% } \\
\text { identity }\end{array}$} & \multirow{2}{*}{ Function } \\
\hline & Rat & Human & & \\
\hline \multirow{2}{*}{ Hypertension and } & $A C E$ & $A C E$ & $83 \%$ & $\begin{array}{l}\text { Involved in the regulation of } \\
\text { blood pressure }\end{array}$ \\
\hline & PTGIS & PTGIS & $80 \%$ & $\begin{array}{l}\text { Synthesis of prostacyclin, a potent } \\
\text { vasodilator }\end{array}$ \\
\hline \multirow[t]{2}{*}{ remodeling } & $R G S 5$ & $R G S 5$ & $89 \%$ & Blood pressure regulation \\
\hline & $T N F \alpha$ & $T N F \alpha$ & $73 \%$ & $\begin{array}{l}\text { Pro-inflammatory cytokine } \\
\text { affecting endothelial function }\end{array}$ \\
\hline
\end{tabular}




\begin{tabular}{|c|c|c|c|c|}
\hline & $I G F 1$ & $I G F 1$ & $85 \%$ & $\begin{array}{l}\text { Mitogen of vascular smooth } \\
\text { muscle cells }\end{array}$ \\
\hline \multirow{4}{*}{$\begin{array}{l}\text { Cardiac } \\
\text { remodeling }\end{array}$} & $T G F \beta 1$ & $T G F \beta 1$ & $90 \%$ & $\begin{array}{l}\text { Regulation of cell proliferation } \\
\text { and differentiation }\end{array}$ \\
\hline & MYH7 & MYH7 & $97 \%$ & $\begin{array}{l}\text { Heavy chain subunit of cardiac } \\
\text { myosin }\end{array}$ \\
\hline & SMAD4 & SMAD4 & $90 \%$ & $\begin{array}{l}\text { Transduces signal from TGF } \beta 1 \text { to } \\
\text { regulate gene expression }\end{array}$ \\
\hline & $B R G 1$ & $B R G 1$ & $99 \%$ & Transcriptional coactivator \\
\hline Polycysctic & PKD1 & PKD1 & $78 \%$ & Role in renal tubulogenesis \\
\hline
\end{tabular}

\section{kidney disease}

* $A C E$, angiotensin I converting enzyme; PTGIS, prostacyclin synthase; $R G S 5$, regulator of $\mathrm{G}$ protein signaling 5; TNF $\alpha$, tumor necrosis factor $\alpha ; I G F 1$, insulin-like growth factor $1 ; T G F \beta 1$, transforming growth factor $\beta 1 ; M Y H 7$, myosin heavy chain $7 ; B R G 1$, brahma-related gene 1 ; PKD1, polycystic kidney disease 1

\section{Statistical Analysis}

Statistical analysis on the systemic hemodynamic data, LV and heart indices and gene expression data was performed using a one way analysis of variance (ANOVA), proceeded by Tukey's honestly significant difference (HSD) post hoc test using either Origin 2017 (OriginLab, Northampton, MA) or Graph Pad Prism (Graph Pad Software, San Diego, CA). Pearson correlation analysis on gene expression data was also performed using Origin 2017 (OriginLab, Northampton, MA). All data are presented as mean $\pm \mathrm{SEM}$ with significance at $\mathrm{P}<0.05$.

\section{Results}

Plasma concentration of $\mathrm{H}_{2} \mathrm{~S}$ and NO 
The concentration of $\mathrm{H}_{2} \mathrm{~S}$ and $\mathrm{NO}$ was significantly lower in the plasma of the LVH rats compared to control group $(\mathrm{P}<0.05) . \mathrm{H}_{2} \mathrm{~S}$ plasma concentration was significantly increased $(\mathrm{P}<0.05)$ on NaHS treatment in control and LVH rats. L-arginine treatment significantly increased $(\mathrm{P}<0.05)$ plasma $\mathrm{H}_{2} \mathrm{~S}$ concentration in control but not in LVH rats, while combined Larginine and NaHS treatment did not significantly increase $\mathrm{H}_{2} \mathrm{~S}$ concentration in LVH, but significantly reduced it in control rats (S1 Fig). NO plasma concentration was significantly increased in individual as well as combined NaHS and L-arginine treatments in both control and LVH rats $(\mathrm{P}<0.05)(\mathrm{S} 2$ Fig $)$.

\section{Treatment $\left(\mathrm{H}_{2} \mathrm{~S}, \mathrm{NO}\right.$ and $\left.\mathrm{H}_{2} \mathrm{~S}+\mathrm{NO}\right)$ ameliorates $\mathrm{LVH}$ progression}

It was observed that the induction of LVH significantly elevated MAP and PWV as compared to control $(\mathrm{P}<0.05)$. Consequently, treatment with $\mathrm{H}_{2} \mathrm{~S}, \mathrm{NO}$ and $\mathrm{H}_{2} \mathrm{~S}+\mathrm{NO}$, significantly reduced MAP by $14 \%, 20 \%$ and $29 \%$ and PWV by $25 \%, 37 \%$ and $12 \%$, respectively, in LVH rats $(\mathrm{P}<0.05)$. Heart rate $(\mathrm{HR})$ was significantly reduced in $\mathrm{LVH}$ rats as compared to control group and $\mathrm{H}_{2} \mathrm{~S}$, NO and $\mathrm{H}_{2} \mathrm{~S}+\mathrm{NO}$ treatment further reduced $\mathrm{HR}$ in $\mathrm{LVH}$ rats $(\mathrm{P}<0.05)$. RCBP was reduced by $\sim 53 \mathrm{bpu}$ in $\mathrm{LVH}$ rats as compared to control $(\mathrm{P}<0.05)$ and $\mathrm{H}_{2} \mathrm{~S}, \mathrm{NO}$ and $\mathrm{H}_{2} \mathrm{~S}+\mathrm{NO}$ treatment resulted in 36\%, 42\% and 79\% higher RCBP compared to untreated LVH rats $(\mathrm{P}<0.05)$ (Table 2).

Table 2. Systemic hemodynamic parameters of the studied animal groups

\begin{tabular}{|c|c|c|c|c|}
\hline \multirow{2}{*}{ Animal Groups } & \multicolumn{4}{|l|}{ Parameters } \\
\hline & MAP (mmHg) & $\mathrm{PWV}(\mathrm{m} / \mathrm{s})$ & HR (bpm) & RCBP (bpu) \\
\hline Control & $119 \pm 1$ & $6 \pm 0.4$ & $314 \pm 3$ & $150 \pm 12$ \\
\hline Control- $\mathrm{H}_{2} \mathbf{S}$ & $122 \pm 6$ & $6 \pm 0.2$ & $293 \pm 3 *$ & $138 \pm 4$ \\
\hline Control-NO & $105 \pm 1$ & $6 \pm 0.3 * \psi$ & $304 \pm 14$ & $132 \pm 3 *$ \\
\hline
\end{tabular}




\begin{tabular}{|c|c|c|c|c|}
\hline Control- $\mathrm{H}_{2} \mathrm{~S}+\mathrm{NO}$ & $117 \pm 4$ & $7 \pm 0.1 * \psi \varphi$ & $280 \pm 13 * \varphi$ & $141 \pm 2$ \\
\hline $\mathrm{LVH}$ & $142 \pm 5 *$ & $8 \pm 0.4 * \psi \varphi \sigma$ & $273 \pm 2 * \psi \varphi$ & $97 \pm 6^{*} \psi \varphi \sigma$ \\
\hline $\mathrm{LVH}_{-\mathrm{H}_{2}} \mathbf{S}$ & $122 \pm 3 \#$ & $6 \pm 0.3^{*} \#$ & $247 \pm 10 * \#$ & $132 \pm 5 * \#$ \\
\hline LVH-NO & $114 \pm 3 \#$ & $5 \pm 0.3 * \#$ & $257 \pm 7 *$ & $138 \pm 9 \#$ \\
\hline LVH-H $\mathbf{H}_{2} \mathbf{S}+\mathbf{N O}$ & $101 \pm 5 * \# \lambda$ & $7 \pm 0.2 \# \lambda \pi$ & $228 \pm 5 * \# \lambda \pi$ & $174 \pm 14 * \# \lambda \pi$ \\
\hline
\end{tabular}

*Data are expressed as mean $\pm \mathrm{SEM}$ and significance taken at $\mathrm{P}<0.05$. * significant vs. control group; $\psi$ significant vs. control- $\mathrm{H}_{2} \mathrm{~S} ; \varphi$ significant vs. control-NO; $\sigma$ significant vs. control$\mathrm{H}_{2} \mathrm{~S}+\mathrm{NO}$; \# significant vs. LVH; $\lambda$ significant vs. $\mathrm{LVH}-\mathrm{H}_{2} \mathrm{~S} ; \pi$ significant vs. LVH-NO.

$†$ MAP, mean arterial pressure; PWV, pulse wave velocity; HR, heart rate; RCBP, renal cortical blood perfusion; Control- $\mathrm{H}_{2} \mathrm{~S}$, NaHS treated control group; Control-NO, L-arginine treated control group; Control- $\mathrm{H}_{2} \mathrm{~S}+\mathrm{NO}$, NaHS and L-arginine combined treated control group; LVH, left ventricular hypertrophy induced rats; LVH- ${ }_{2} \mathrm{~S}$, NaHS treated LVH rats; LVH-NO, Larginine treated $\mathrm{LVH}$ rats; $\mathrm{LVH}-\mathrm{H}_{2} \mathrm{~S}+\mathrm{NO}$, NaHS and L-arginine combined treated $\mathrm{LVH}$ rats.

As a measure of heart and kidney physical parameters, heart, LV index and renal indices were observed to increase by about $46 \%, 53 \%$ and $17 \%(\mathrm{P}<0.05)$, respectively, in $\mathrm{LVH}$ rats as compared to control group and treatment with $\mathrm{H}_{2} \mathrm{~S}$ and NO reduced these parameters; combined treatment reduced heart, LV index and renal indices by $41 \%, 22 \%$ and $9 \%(\mathrm{P}<0.05)$, respectively. Moreover, induction of $\mathrm{LVH}$ increased the myocardium thickness by $1.6 \mathrm{~mm}$ and reduced LV chamber diameter by $\sim 2 \mathrm{~mm}$ and $\mathrm{H}_{2} \mathrm{~S}$ and $\mathrm{NO}$ treatment decreased myocardium thickness and increased LV chamber diameter $(\mathrm{P}<0.05) . \mathrm{H}_{2} \mathrm{~S}+\mathrm{NO}$ treatment reduced thickness of the myocardium by $36 \%$ and increased LV chamber diameter by $43 \%$ in LVH rats (Table 3 ). 
Table 3. Heart and kidney physical parameters of the studied animal groups.

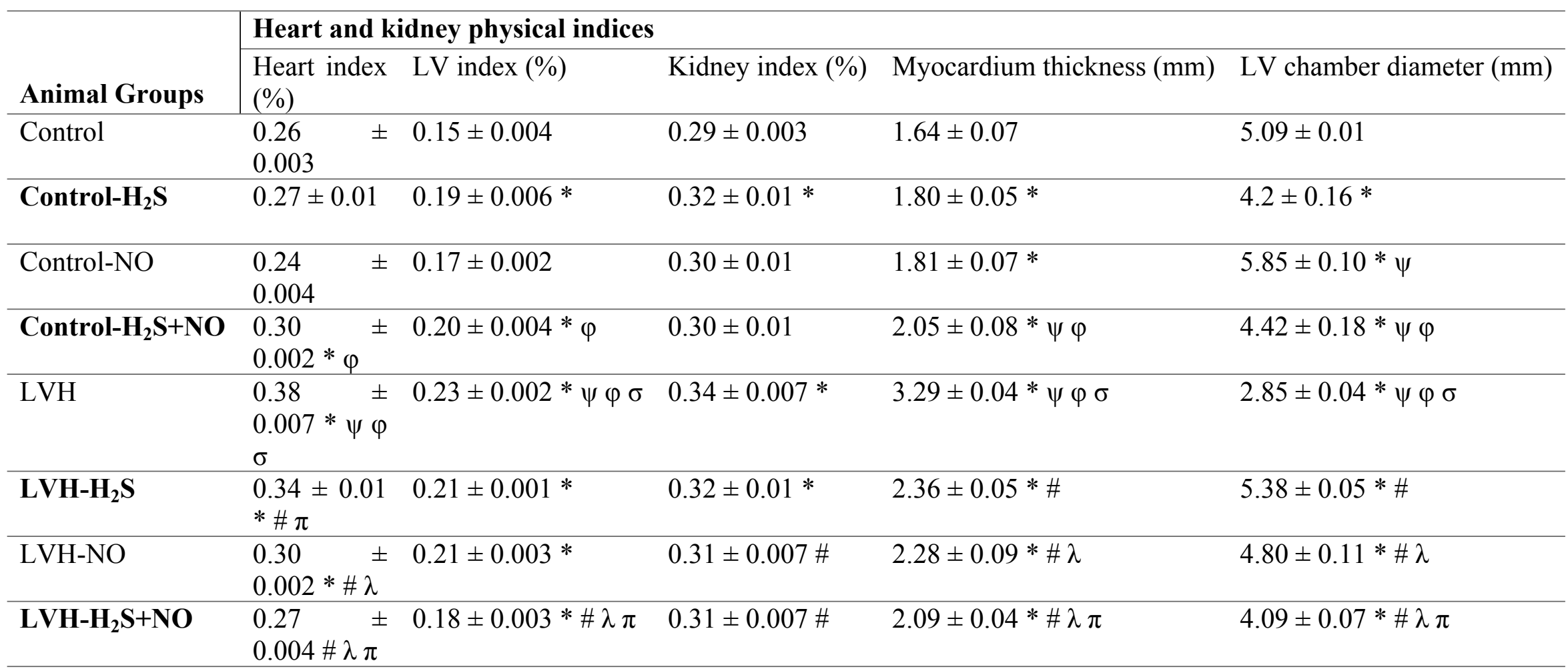

$*$ Data are expressed as mean $\pm \mathrm{SEM}$ and significance taken at $\mathrm{P}<0.05 . *$ significant vs. control group; $\psi$ significant vs. control- $\mathrm{H}_{2} \mathrm{~S} ; \varphi$ significant vs. control-NO; $\sigma$ significant vs. control- $\mathrm{H}_{2} \mathrm{~S}+\mathrm{NO}$; \# significant vs. LVH; $\lambda$ significant vs. LVH- $\mathrm{H}_{2} \mathrm{~S} ; \pi$ significant vs. LVH-NO. 


\section{Expression modulation of hypertension and vascular remodeling genes under $\mathrm{H}_{2} \mathrm{~S}$, NO, and}

\section{$\mathrm{H}_{2} \mathrm{~S}+\mathrm{NO}$ treatment}

There was a $\sim 2$ fold increase in $A C E$ expression in the myocardium and $\sim 7.5$ fold increase in $A C E$ expression in the renal tissue of $\mathrm{LVH}$ rats as compared to control $(\mathrm{P}<0.05)$. In both, heart and kidney, $\mathrm{H}_{2} \mathrm{~S}$ treatment in control significantly up-regulated $A C E$ expression while $\mathrm{H}_{2} \mathrm{~S}$ treatment in $\mathrm{LVH}$ rats significantly reduced $A C E$ expression (both $\mathrm{P}<0.05$ ). NO treatment significantly down-regulated $A C E$ expression in both control and LVH group myocardia and kidneys (both $\mathrm{P}<0.05$ ). Combined treatment with $\mathrm{H}_{2} \mathrm{~S}+\mathrm{NO}$ significantly down-regulated $(\mathrm{P}<0.05) A C E$ in kidney of LVH rats, however, down-regulation of $A C E$ expression was not significant in heart $(\mathrm{P}>0.05)$ (Fig 1A). PTGIS expression increased by 1.5 fold in heart tissue of LVH rats as compared to control and $\mathrm{H}_{2} \mathrm{~S}$ and $\mathrm{H}_{2} \mathrm{~S}+\mathrm{NO}$ treatment showed significant downregulation, while NO treatment increased expression in heart tissue of LVH rats $(\mathrm{P}<0.05)$. Contrarily, in renal tissue PTGIS expression was significantly down-regulated in LVH group as compared to control, however, individual as well as combined $\mathrm{H}_{2} \mathrm{~S}$ and NO treatment upregulated PTGIS in LVH rats $(\mathrm{P}<0.05)$ (Fig $1 \mathrm{~B})$. RGS5 was $0.2-0.3$ fold down-regulated in both heart and renal tissues of $\mathrm{LVH}$ as compared to control group $(\mathrm{P}<0.05)$ but there was no notable significant change in gene expression of $R G S 5$ after $\mathrm{H}_{2} \mathrm{~S}$, NO and $\mathrm{H}_{2} \mathrm{~S}+\mathrm{NO}$ treatment in LVH rats (Fig 1C).

\section{Fig 1. Graphical representation of relative gene expression of hypertension, vascular}

remodeling genes. Graph showing the relative gene expression in control, left ventricular hypertrophy $(\mathrm{LVH})$ and treated groups in cardiac and renal tissues of hypertension, vascular remodeling genes. Relative gene expression of (A) $A C E$, (B) PTGIS, (C) RGS5, (D) TNFa, (E) 
$I G F 1$, in cardiac and renal tissues of control, $\mathrm{LVH}, \mathrm{H}_{2} \mathrm{~S}$ and $\mathrm{NO}$ treated and $\mathrm{H}_{2} \mathrm{~S}+\mathrm{NO}$ combined treated rats.

$T N F \alpha$ was significantly up-regulated in both renal and heart tissues of LVH WKY as compared to control $(\mathrm{P}<0.05)$, while $\mathrm{H}_{2} \mathrm{~S}$, NO and $\mathrm{H}_{2} \mathrm{~S}+\mathrm{NO}$ treatment significantly down-regulated TNF $\alpha$ expression in kidney $(\mathrm{P}<0.05)$, however, it's expression did not alter in response to $\mathrm{H}_{2} \mathrm{~S}$ and $\mathrm{H}_{2} \mathrm{~S}+\mathrm{NO}$ treatment while NO treatment significantly increased expression in heart tissue of LVH rats (Fig 1D). IGF1 expression was significantly up-regulated in myocardia and renal tissues of LVH group as compared to control while $\mathrm{H}_{2} \mathrm{~S}$, $\mathrm{NO}$ and combined $\mathrm{H}_{2} \mathrm{~S}+\mathrm{NO}$ treatment significantly down-regulated it normal or near to normal $(\mathrm{P}<0.05)$ (Fig 1E).

Change in cardiac remodeling gene expression in myocardia in response to $\mathrm{H}_{2} \mathrm{~S}$, NO, and $\mathrm{H}_{2} \mathrm{~S}+\mathrm{NO}$ treatment

Expression of cardiac remodeling genes was studied in the myocardia of LVH rats in response to treatment, $M Y H 7, T G F \beta 1, B R G 1$ and SMAD4 expression was observed to be significantly upregulated in myocardia of $\mathrm{LVH}$ as compared to control group (all $\mathrm{P}<0.05)($ Fig 2$) . \mathrm{H}_{2} \mathrm{~S}$ treatment significantly increased $M Y H 7$ expression but there was no significant change in $T G F \beta 1, B R G 1$ and SMAD4 expression in response to $\mathrm{H}_{2} \mathrm{~S}$; however, NO treatment significantly reduced $M Y H 7$ and BRG1 expression but had no significant effect on $T G F \beta 1$ and SMAD4 expression in the myocardia of $\mathrm{LVH}$ rats. Combined $\mathrm{H}_{2} \mathrm{~S}+\mathrm{NO}$ treatment did not significantly change the expression of MYH7, BRG1 and SMAD4 in the myocardia of the LVH group. However, TGF $\beta 1$ expression was significantly down-regulated $(\mathrm{P}<0.05)$ in $\mathrm{LVH}$ myocardia treated with $\mathrm{H}_{2} \mathrm{~S}+\mathrm{NO}$ (Fig 2). 
Fig 2. Graph showing the relative gene expression in control, LVH and treated groups of cardiac remodeling genes in cardiac tissue. Relative gene expression of $M Y H 7, T G F \beta 1$, SMAD4 and BRG1, in heart tissues of control, $\mathrm{LVH}, \mathrm{H}_{2} \mathrm{~S}$ and $\mathrm{NO}$ treated and $\mathrm{H}_{2} \mathrm{~S}+\mathrm{NO}$ combined treated rats.

\section{Altered $P K D 1$ expression in renal tissues of $\mathrm{H}_{2} \mathrm{~S}$, NO, and $\mathrm{H}_{2} \mathrm{~S}+\mathrm{NO}$ treated rats}

Hypertension induced $\mathrm{LVH}$ is an important complication in polycystic kidney disease (PKD) [31] and to elucidate the effect of $\mathrm{H}_{2} \mathrm{~S}$ and $\mathrm{NO}$ treatment on hypertensive nephropathy in LVH rats we studied $P K D 1$ expression in $\mathrm{LVH}$ rats before and after treatment. About 3-fold increase in PKDl expression was observed in renal tissue of LVH WKY as compared to control group $(\mathrm{P}<0.05)$. PKD1 expression was significantly down-regulated after treatment of LVH rats with $\mathrm{H}_{2} \mathrm{~S}$, NO and $\mathrm{H}_{2} \mathrm{~S}$ and $\mathrm{NO}$ combined $(\mathrm{P}<0.05)$ (Fig 3).

Fig 3. Graph showing the relative gene expression of $P K D 1$ in control $L V H$ and treated groups in renal tissue.

\section{Discussion}

In this study we aimed to elucidate the modulation in expression of particular orthologous genes upon gasotransmitters, $\mathrm{H}_{2} \mathrm{~S}$ and $\mathrm{NO}$, treatment in $\mathrm{LVH}$ rats, these genes are known to have a role in hypertension, vascular and cardiac remodeling and hypertensive nephropathy in humans. The significant decrease in MAP, heart index, LV index and myocardium thickness, increase in RCBP, and modulated expression of ACE, PTGIS, IGF1, TNF,$T G F \beta 1$ and PKD1 upon exogenous administration of $\mathrm{H}_{2} \mathrm{~S}+\mathrm{NO}$, as compared to individual treatments, showed that combined treatment may be more effective in ameliorating LVH and its complications. 
Comparison of the pattern of gene expression between all animal groups showed that gene expression was most dissimilar in control and LVH groups, while expression was most similar in control and $\mathrm{H}_{2} \mathrm{~S}+\mathrm{NO}$ treated $\mathrm{LVH}$ groups (Fig 4; $\mathrm{S} 1$ Table) thus indicating that $\mathrm{H}_{2} \mathrm{~S}+\mathrm{NO}$ treatment has promising therapeutic potential in LVH and associated complications.

Fig 4. Heatmap showing the comparative relationship of gene expression among studied groups as tested in cardiac and renal tissues.

We previously reported an up-regulation in endothelial nitric oxide synthase (eNOS) and cystathione-gamma lyase (CSE) expression upon exogenous $\mathrm{H}_{2} \mathrm{~S}$ administration only [30]. We also reported that individual NO treatment up-regulated eNOS expression in control and LVH rats and CSE expression in control rats, but down-regulated CSE expression in LVH rats [27]. In our previous report on $\mathrm{H}_{2} \mathrm{~S}+\mathrm{NO}$ treatment we showed that CSE mRNA levels significantly decreased in control but not in LVH rats, while eNOS mRNA levels significantly increased in both LVH and control groups). Extending our study to check $\mathrm{H}_{2} \mathrm{~S}$ and $\mathrm{NO}$ plasma concentrations, we have found that these changes corresponded to the mRNA levels of their respective synthases. The synthesis of biochemical intermediates and modulation of the respective pathways for $\mathrm{NO}$ and $\mathrm{H}_{2} \mathrm{~S}$ synthesis by the gasotransmitters may explain the synergistic efficiency of combined $\mathrm{H}_{2} \mathrm{~S}$ and $\mathrm{NO}$ treatment in ameliorating $\mathrm{LVH}$ relative to individual treatments.

The effect of individual and combined treatment with $\mathrm{H}_{2} \mathrm{~S}$ and $\mathrm{NO}$ was also seen on the expression of genes in LVH WKY rats. Induction of LVH significantly up-regulated $A C E$ expression while $\mathrm{H}_{2} \mathrm{~S}+\mathrm{NO}$ treatment down-regulated $A C E$ expression in kidney and heart tissues. Previous studies have reported a two to three fold increase in Angiotensin II (Ang II) levels in 
isoprenaline induced LVH WKY rats [30,32], which indicates an activation of RAS, resulting in hypertension and arterial stiffness in these LVH models. Being a human ortholog, DNA sequence variations in $A C E$ affects circulating $\mathrm{ACE}$ concentration and is linked to the development of LVH in humans. The DD genotype of an insertion/deletion (I/D) polymorphism results in elevated ACE plasma levels and is associated with an increased LV mass index [33] and a $2350 \mathrm{G}>\mathrm{A}$ polymorphism that affects plasma ACE levels is also associated with LVH [34]. Moreover, ACE inhibitors have been shown to be less effective in LVH regression in patients with the DD genotype [35]. The down-regulation of $A C E$ expression upon $\mathrm{H}_{2} \mathrm{~S}+\mathrm{NO}$ treatment in the present study indicates that combined treatment may alleviate hypertension caused by either endogenous or exogenous RAS activation. It was also observed that $\mathrm{H}_{2} \mathrm{~S}$ treatment in control WKY rats significantly up-regulates $A C E$ expression, which indicates that there may be a difference in the effects elicited by exogenous treatment with gasotransmitters in diseased as opposed to normal settings.

PTGIS catalyzes prostacyclin synthesis from prostaglandin $\mathrm{H} 2$ and primarily found in smooth muscle and vascular endothelial cells [36]; prostacyclin suppresses smooth muscle cell proliferation and platelet aggregation and promotes vasodilation [37]. We found a significant upregulation of PTGIS expression in LVH rats as compared to control, while $\mathrm{H}_{2} \mathrm{~S}+\mathrm{NO}$ treatment down-regulated its expression in LVH rats. This is in line with already reported data in which Champetier et al. [38] observed a 1.9 fold increase in PTGIS expression in LV of rats with severe aortic regurgitation, which is associated with left ventricle eccentric hypertrophy, Harding et al. [39] however, reported an anti-hypertrophic nature of prostacyclin and its inhibitory effect on cardiac fibrosis. Genetic changes and epigenetic modifications are known to alter human PTGIS ortholog expression where promoter hypermethylation results in reduced expression of PTGIS 
[40]. Based on our findings, there is a significant down-regulation of PTGIS in LVH kidney and combined $\mathrm{H}_{2} \mathrm{~S}+\mathrm{NO}$ treatment up-regulates expression, which is contrary to the gene expression changes in the myocardium. A critical role for prostacyclin in renal development has been shown previously and PTGIS-knockout mice showed severely abnormal glomerular, vascular and interstitial development [41]. There might be a role of epigenetics in differential gene expression between the two tissues, thus indicating the treatment effectiveness also against epigenetic changes in a tissue specific manner.

RGS5 is one of the regulators of G-protein signaling and it is expressed in vascular and cardiac muscle tissues [42] where it serves to inhibit several Gai- and Gaq-mediated signaling pathways including those that are induced by Ang II $[42,43]$. RGS5 human ortholog has been shown to be associated with blood pressure control [44], while, our data has demonstrated a significant reduction in RGS5 mRNA, hence diminishing its protective role against Ang II mediated signaling, in the heart and kidney tissue of LVH WKY rats as compared to control group and there was no notable change in $R G S 5$ expression following $\mathrm{H}_{2} \mathrm{~S}+\mathrm{NO}$ treatment. In addition, $R G S 5$ expression in heart negatively correlated to the expression of $A C E, T G F \beta 1$ and IGF1 in the heart in the current study (Fig 4; S1 Table)

IGF1 promotes cell division, it is an antiapoptotic factor in vascular and endothelial cells and promotes cardiac growth and function [45]. Donohue et al. [46] have reported that development of hypertension and hypertrophy was associated with increased IGF1 mRNA levels in rats. Similarly, Li et al. $[47,48]$ found mRNA and protein levels of the human ortholog to be elevated in idiopathic hypertrophic obstructive cardiomyopathy (HOCM) tissues. Increased IGF1 levels in hypertensive patients as opposed to normotensive individuals is associated with increase in pressure load [49] and is also shown to be positively associated with chronic renal disease [50]. 
Moreover, promoter polymorphisms in IGF1 have been shown to be significantly related to LV mass in male athletes [51]. We found IGF1 expression to be up-regulated in LVH and significant reduction in expression upon $\mathrm{H}_{2} \mathrm{~S}+\mathrm{NO}$ treatment. TNF $\alpha$, an inflammatory cytokine has been shown to effect left ventricular remodeling and hypertrophy under hypertension [52] and is a crucial player in the hypertension and cardiac remodeling processes induced by Ang II [53]. TNF-knockout mice have displayed diminished hypertensive response on activation of RAS [54]. The human $T N F \alpha$ ortholog by Patel et al. [55] had shown variable expression of $T N F \alpha$ in hypertrophic cardiomyopathy $(\mathrm{HCM})$ patients having the AA genotype of $T N F \alpha-308 \mathrm{G}>\mathrm{A}$ functional single nucleotide polymorphism, resulting in greater LV mass index development and clinical diagnosis at a younger age. TNF $\alpha$ has been shown to further the progression of cyst formation particularly in an autosomal dominant polycystic kidney disease (ADPKD) genetic background [56]. Our data demonstrates up-regulation of $T N F \alpha$ expression in kidney and heart tissues of LVH WKY rats and a significant reduction in TNF $\alpha$ expression in kidney upon NO and $\mathrm{H}_{2} \mathrm{~S}+\mathrm{NO}$ treatment, moreover, $T N F \alpha$ expression showed strong positive correlation with PKD1 expression (r=0.9) (Fig 4; S1 Table).

The heart muscle responds to cardiac workload and hemodynamic stress by activation of the fetal gene expression program, causing hypertrophic growth [57]. In rats, MYH7 ( $\beta$-MHC) is the fetal isoform of myosin heavy chain that is shown to be up-regulated in cardiac hypertrophy [58], which is consistent with our findings, where we also observed its higher expression. This $M Y H 7$ overexpression was slightly down-regulated upon LVH regression after $\mathrm{H}_{2} \mathrm{~S}+\mathrm{NO}$ treatment, although this was not statistically significant. It has been shown by Lowes et al. [59] that $\beta$-MHC human ortholog expression increases and expression of $\alpha$-MHC isoform is reduced in ventricular myocardium in failing hearts. TGF $\beta 1$ promotes cardiac remodeling and hypertrophy in response 
to pressure overload [60]. It has been reported previously that an increase in cardiac $T G F \beta 1$ mRNA in response to AngII infusion in mice and $T N F \alpha$ deficient mice failed to elicit this increase [53]. On comparing hypertensive and normotensive individuals, Argano et al. [61] reported a polymorphism in human $T G F \beta 1$ ortholog affecting TGF $\beta 1$ sera levels which was found to be associated with hypertension, left ventricular hypertrophy and renal damage. SMAD proteins are transcription activators that are involved in the transduction of TGF $\beta 1$ signal [60]. SMAD4 is a crucial part of TGF $\beta 1$ signaling pathway [62] and it is reported to induce apoptosis and negative remodeling in hypertrophied myocardia [63]. BRG1 is a chromatin modifying protein that is involved in the switch to fetal MHC expression, promoting hypertrophy [64] and it is reported to be inhibited by $\mathrm{H}_{2} \mathrm{~S}$ [65]. In line with this literature, our data demonstrates a significant increase in $T G F \beta 1, S M A D 4$ and $B R G 1$ mRNA in LVH WKY rats. While TGF $\beta 1$ expression was significantly reduced in response to $\mathrm{H}_{2} \mathrm{~S}+\mathrm{NO}$ treatment, SMAD4 and BRG1 expression did not change significantly following treatment. We also observed change in $T G F \beta 1$, MYH7, SMAD4 and BRG1 expression and moderate to strong correlation between these components (Fig 4; S1 Table).

Another interesting finding of the current study is the modulation in PKDI expression in LVH rat, in response to treatment. $P K D 1$ encodes polycystin-1 which is an integral membrane protein expressed in the renal tubular epithelium [66]. Studies have shown that altered PKDI expression may lead to cyst formation in polycystic kidney disease (PKD) [67,68]. Cardiovascular abnormalities such as hypertension and LVH are frequently associated with autosomal-dominant PKD (ADPKD) [69]. We found PKD1 to be $~ 3$-fold up-regulated on induction of LVH in WKY rats and individual treatments as well as combined treatment with $\mathrm{H}_{2} \mathrm{~S}$ and NO significantly down-regulated PKD1 expression. Moreover, PKD1 expression showed a strong positive 
correlation with $A C E, T N F \alpha$ and $I G F 1$ expression in the kidney (Fig 4; S1 Table), the genes that are involved in hypertrophy and vascular remodeling in the heart as well as kidney.

\section{Conclusion}

In summary, in the present study, there was a modulation of expression of the hypertrophy, vascular and cardiac remodeling and hypertensive nephropathy genes in LVH rat model and combined treatment with $\mathrm{H}_{2} \mathrm{~S}$ and $\mathrm{NO}$, effectively normalized gene expression in most cases. Human orthologs of these genes have crucial roles in the development of hypertension induced LVH and related complications, which thus highlights a promising therapeutic role for $\mathrm{H}_{2} \mathrm{~S}$ and NO combined treatment. Taken together, the present data therefore suggest that combined treatment of $\mathrm{H}_{2} \mathrm{~S}$ and $\mathrm{NO}$ may be used as a therapeutic intervention for renal and cardiac protection directly and/or indirectly (Fig 5).

Fig 5. Therapeutic potential of gasotransmitters in left ventricular hypertrophy. Combined treatment of $\mathrm{H}_{2} \mathrm{~S}+\mathrm{NO}$ has cytoprotective effect in cardiac and renal tissues in left ventricular hypertrophy. The yellow font represents up-regulation while green font represents downregulation of the studied genes. The dotted arrow is indicative of predicted direct action.

\section{Funding}

This work was funded by [core grant of CIIT to RQ] and grants from the Higher Education Commission of Pakistan [Grant No. 3738 to MA and RQ] and [Grant No. 5406 to MA and RQ].

\section{Acknowledgements}

The authors thank all the technician and staff of the labs for facilitation during the course of study. 


\section{Conflict of interest}

None of the authors declare any conflict of interest.

\section{References}

1. Sadoshima J, Izumo S. The cellular and molecular response of cardiac myocytes to mechanical stress. Annu Rev Physiol 1997;59:551-71.

2. Guyton AC. The surprising kidney-fluid mechanism for pressure control--its infinite gain! Hypertension 1990;16(6):725-30.

3. Cannon PJ. The kidney in heart failure. N Engl J Med 1977;296(1):26-32.

4. Hamasaki S, Al Suwaidi J, Higano ST, Miyauchi K, Holmes DR, Jr., Lerman A. Attenuated coronary flow reserve and vascular remodeling in patients with hypertension and left ventricular hypertrophy. J Am Coll Cardiol 2000;35(6):1654-60.

5. Taegtmeyer H, Sen S, Vela D. Return to the fetal gene program: a suggested metabolic link to gene expression in the heart. Ann N Y Acad Sci 2010;1188:191-8.

6. Naseem KM. The role of nitric oxide in cardiovascular diseases. Mol Aspects Med $2005 ; 26(1-2): 33-65$.

7. Shen Y, Shen Z, Luo S, Guo W, Zhu YZ. The Cardioprotective Effects of Hydrogen Sulfide in Heart Diseases: From Molecular Mechanisms to Therapeutic Potential. Oxid Med Cell Longev 2015;2015:925167.

8. Shibuya N, Mikami Y, Kimura Y, Nagahara N, Kimura H. Vascular endothelium expresses 3-mercaptopyruvate sulfurtransferase and produces hydrogen sulfide. J Biochem 2009;146(5):623-6.

9. Moncada S, Palmer RM, Higgs EA. Nitric oxide: physiology, pathophysiology, and pharmacology. Pharmacol Rev 1991;43(2):109-42. 
10. Mishra PK, Tyagi N, Sen U, Givvimani S, Tyagi SC. H2S ameliorates oxidative and proteolytic stresses and protects the heart against adverse remodeling in chronic heart failure. Am J Physiol Heart Circ Physiol 2010;298(2):H451-6.

11. Lu F, Xing J, Zhang X, Dong S, Zhao Y, Wang L, Li H, Yang F, Xu C, Zhang W. Exogenous hydrogen sulfide prevents cardiomyocyte apoptosis from cardiac hypertrophy induced by isoproterenol. Mol Cell Biochem 2013;381(1-2):41-50.

12. Yang F, Liu Z, Wang Y, Li Z, Yu H, Wang Q. Hydrogen sulfide endothelin-induced myocardial hypertrophy in rats and the mechanism involved. Cell Biochem Biophys 2014;70(3):1683-6.

13. Huang J, Wang D, Zheng J, Huang X, Jin H. Hydrogen sulfide attenuates cardiac hypertrophy and fibrosis induced by abdominal aortic coarctation in rats. Mol Med Rep 2012;5(4):923-8.

14. Barouch LA, Cappola TP, Harrison RW, Crone JK, Rodriguez ER, Burnett AL, Hare JM. Combined loss of neuronal and endothelial nitric oxide synthase causes premature mortality and age-related hypertrophic cardiac remodeling in mice. J Mol Cell Cardiol 2003;35(6):637-44.

15. Matsuoka H, Nakata M, Kohno K, Koga Y, Nomura G, Toshima H, Imaizumi T. Chronic L-arginine administration attenuates cardiac hypertrophy in spontaneously hypertensive rats. Hypertension 1996;27(1):14-8.

16. Yong QC, Cheong JL, Hua F, Deng LW, Khoo YM, Lee HS, Perry A, Wood M, Whiteman M, Bian JS. Regulation of heart function by endogenous gaseous mediators-crosstalk between nitric oxide and hydrogen sulfide. Antioxid Redox Signal 2011;14(11):2081-91.

17. Nagpure BV, Bian JS. Interaction of Hydrogen Sulfide with Nitric Oxide in the Cardiovascular System. Oxid Med Cell Longev 2016;2016:6904327. 
18. Snijder PM, Frenay AR, Koning AM, Bachtler M, Pasch A, Kwakernaak AJ, van den Berg E, Bos EM, Hillebrands JL, Navis G, Leuvenink HG, van Goor H. Sodium thiosulfate attenuates angiotensin II-induced hypertension, proteinuria and renal damage. Nitric Oxide 2014;42:87-98.

19. Sen U, Basu P, Abe OA, Givvimani S, Tyagi N, Metreveli N, Shah KS, Passmore JC, Tyagi SC. Hydrogen sulfide ameliorates hyperhomocysteinemia-associated chronic renal failure. Am J Physiol Renal Physiol 2009;297(2):F410-9.

20. Regner KR, Roman RJ. Role of medullary blood flow in the pathogenesis of renal ischemia-reperfusion injury. Curr Opin Nephrol Hypertens 2012;21(1):33-8.

21. Xia M, Chen L, Muh RW, Li PL, Li N. Production and actions of hydrogen sulfide, a novel gaseous bioactive substance, in the kidneys. J Pharmacol Exp Ther 2009;329(3):1056-62.

22. Baylis C. Arginine, arginine analogs and nitric oxide production in chronic kidney disease. Nat Clin Pract Nephrol 2006;2(4):209-20.

23. Raij L, Baylis C. Glomerular actions of nitric oxide. Kidney Int 1995;48(1):20-32.

24. Singh RR, Easton LK, Booth LC, Schlaich MP, Head GA, Moritz KM, Denton KM. Renal Nitric Oxide Deficiency and Chronic Kidney Disease in Young Sheep Born with a Solitary Functioning Kidney. Sci Rep 2016;6:26777.

25. Ahmad A, Sattar MA, Rathore HA, Abdulla MH, Khan SA, Abdullah NA, Kaur G, Johns EJ. Functional contribution of alpha1D-adrenoceptors in the renal vasculature of left ventricular hypertrophy induced with isoprenaline and caffeine in Wistar-Kyoto rats. Can J Physiol Pharmacol 2014;92(12):1029-35.

26. Yan H, Du J, Tang C. The possible role of hydrogen sulfide on the pathogenesis of spontaneous hypertension in rats. Biochem Biophys Res Commun 2004;313(1):22-7. 
27. Ahmad A, Sattar MA, Rathore HA, Abdulla MH, Khan SA, Abdullah NA, Johns EJ. Enhanced expression of endothelial nitric oxide synthase in the myocardium ameliorates the progression of left ventricular hypertrophy in L-arginine treated Wistar-Kyoto rats. J Physiol Pharmacol 2016;67(1):31-44.

28. Gwathmey JK, Kim CS, Hajjar RJ, Khan F, DiSalvo TG, Matsumori A, Bristow MR. Cellular and molecular remodeling in a heart failure model treated with the beta-blocker carteolol. Am J Physiol 1999;276(5 Pt 2):H1678-90.

29. Anand Swarup KR, Sattar MA, Abdullah NA, Abdulla MH, Salman IM, Rathore HA, Johns EJ. Effect of dragon fruit extract on oxidative stress and aortic stiffness in streptozotocininduced diabetes in rats. Pharmacognosy Res 2010;2(1):31-5.

30. Ahmad A, Sattar MA, Rathore HA, Abdulla MH, Khan SA, Azam M, Abdullah NA, Johns EJ. Up Regulation of cystathione gamma lyase and Hydrogen Sulphide in the Myocardium Inhibits the Progression of Isoproterenol-Caffeine Induced Left Ventricular Hypertrophy in Wistar Kyoto Rats. PLoS One 2016;11(3):e0150137.

31. Alam A, Perrone RD. Left ventricular hypertrophy in ADPKD: changing demographics. Curr Hypertens Rev 2013;9(1):27-31.

32. Leenen FH, White R, Yuan B. Isoproterenol-induced cardiac hypertrophy: role of circulatory versus cardiac renin-angiotensin system. Am J Physiol Heart Circ Physiol 2001;281(6):H2410-6.

33. Cosenso-Martin LN, Vaz-de-Melo RO, Pereira LR, Cesarino CB, Yugar-Toledo JC, Cipullo JP, de Souza Pinhel MA, Souza DR, Vilela-Martin JF. Angiotensin-converting enzyme insertion/deletion polymorphism, 24-h blood pressure profile and left ventricular hypertrophy in hypertensive individuals: a cross-sectional study. Eur J Med Res 2015;20:74. 
34. Pan M, Zhu JH, Liu ZH, Jiang WP, Cui ZC, Yu XH, Li HM, Yang XJ. Angiotensinconverting enzyme gene $2350 \mathrm{G} / \mathrm{A}$ polymorphism is associated with left ventricular hypertrophy but not essential hypertension. Hypertens Res 2007;30(1):31-7.

35. Kohno M, Yokokawa K, Minami M, Kano H, Yasunari K, Hanehira T, Yoshikawa J. Association between angiotensin-converting enzyme gene polymorphisms and regression of left ventricular hypertrophy in patients treated with angiotensin-converting enzyme inhibitors. Am J Med 1999;106(5):544-9.

36. Bunting S, Moncada S, Vane JR. The prostacyclin--thromboxane A2 balance: pathophysiological and therapeutic implications. Br Med Bull 1983;39(3):271-6.

37. Moncada S, Gryglewski R, Bunting S, Vane JR. An enzyme isolated from arteries transforms prostaglandin endoperoxides to an unstable substance that inhibits platelet aggregation. Nature 1976;263(5579):663-5.

38. Champetier S, Bojmehrani A, Beaudoin J, Lachance D, Plante E, Roussel E, Couet J, Arsenault M. Gene profiling of left ventricle eccentric hypertrophy in aortic regurgitation in rats: rationale for targeting the beta-adrenergic and renin-angiotensin systems. Am J Physiol Heart Circ Physiol 2009;296(3):H669-77.

39. Harding $\mathrm{P}$, Murray DB. The contribution of prostaglandins versus prostacyclin in ventricular remodeling during heart failure. Life Sci 2011;89(19-20):671-6.

40. Sadler T, Bhasin JM, Xu Y, Barnholz-Sloan J, Chen Y, Ting AH, Stylianou E. Genomewide analysis of DNA methylation and gene expression defines molecular characteristics of Crohn's disease-associated fibrosis. Clin Epigenetics 2016;8:30. 
41. Yokoyama C, Yabuki T, Shimonishi M, Wada M, Hatae T, Ohkawara S, Takeda J, Kinoshita T, Okabe M, Tanabe T. Prostacyclin-deficient mice develop ischemic renal disorders, including nephrosclerosis and renal infarction. Circulation 2002;106(18):2397-403.

42. Manzur M, Ganss R. Regulator of $G$ protein signaling 5: a new player in vascular remodeling. Trends Cardiovasc Med 2009;19(1):26-30.

43. Xiao B, Zhang Y, Niu WQ, Gao PJ, Zhu DL. Haplotype-based association of regulator of G-protein signaling 5 gene polymorphisms with essential hypertension and metabolic parameters in Chinese. Clin Chem Lab Med 2009;47(12):1483-8.

44. Chang YP, Liu X, Kim JD, Ikeda MA, Layton MR, Weder AB, Cooper RS, Kardia SL, Rao DC, Hunt SC, Luke A, Boerwinkle E, Chakravarti A. Multiple genes for essentialhypertension susceptibility on chromosome 1q. Am J Hum Genet 2007;80(2):253-64.

45. Ren J, Samson WK, Sowers JR. Insulin-like growth factor I as a cardiac hormone: physiological and pathophysiological implications in heart disease. J Mol Cell Cardiol 1999;31(11):2049-61.

46. Donohue TJ, Dworkin LD, Lango MN, Fliegner K, Lango RP, Benstein JA, Slater WR, Catanese VM. Induction of myocardial insulin-like growth factor-I gene expression in left ventricular hypertrophy. Circulation 1994;89(2):799-809.

47. Li RK, Li G, Mickle DA, Weisel RD, Merante F, Luss H, Rao V, Christakis GT, Williams WG. Overexpression of transforming growth factor-betal and insulin-like growth factor-I in patients with idiopathic hypertrophic cardiomyopathy. Circulation 1997;96(3):874-81.

48. Li G, Li RK, Mickle DA, Weisel RD, Merante F, Ball WT, Christakis GT, Cusimano RJ, Williams WG. Elevated insulin-like growth factor-I and transforming growth factor-beta 1 and 
their receptors in patients with idiopathic hypertrophic obstructive cardiomyopathy. A possible mechanism. Circulation 1998;98(19 Suppl):II144-9; discussion II149-50.

49. Andronico G, Mangano MT, Ferrara L, Lamanna D, Mule G, Cerasola G. Insulin-like growth factor 1 and pressure load in hypertensive patients. Am J Hypertens 1996;9(6):607-9.

50. Teppala S, Shankar A, Sabanayagam C. Association between IGF-1 and chronic kidney disease among US adults. Clin Exp Nephrol 2010;14(5):440-4.

51. Karlowatz RJ, Scharhag J, Rahnenfuhrer J, Schneider U, Jakob E, Kindermann W, Zang KD. Polymorphisms in the IGF1 signalling pathway including the myostatin gene are associated with left ventricular mass in male athletes. Br J Sports Med 2011;45(1):36-41.

52. Sun M, Chen M, Dawood F, Zurawska U, Li JY, Parker T, Kassiri Z, Kirshenbaum LA, Arnold M, Khokha R, Liu PP. Tumor necrosis factor-alpha mediates cardiac remodeling and ventricular dysfunction after pressure overload state. Circulation 2007;115(11):1398-407.

53. Sriramula S, Francis J. Tumor Necrosis Factor - Alpha Is Essential for Angiotensin IIInduced Ventricular Remodeling: Role for Oxidative Stress. PLoS One 2015;10(9):e0138372.

54. Zhang J, Patel MB, Griffiths R, Mao A, Song YS, Karlovich NS, Sparks MA, Jin H, Wu M, Lin EE, Crowley SD. Tumor necrosis factor-alpha produced in the kidney contributes to angiotensin II-dependent hypertension. Hypertension 2014;64(6):1275-81.

55. Patel R, Lim DS, Reddy D, Nagueh SF, Lutucuta S, Sole MJ, Zoghbi WA, Quinones MA, Roberts R, Marian AJ. Variants of trophic factors and expression of cardiac hypertrophy in patients with hypertrophic cardiomyopathy. J Mol Cell Cardiol 2000;32(12):2369-77.

56. Li X, Magenheimer BS, Xia S, Johnson T, Wallace DP, Calvet JP, Li R. A tumor necrosis factor-alpha-mediated pathway promoting autosomal dominant polycystic kidney disease. Nat Med 2008;14(8):863-8. 
57. Rajabi M, Kassiotis C, Razeghi P, Taegtmeyer H. Return to the fetal gene program protects the stressed heart: a strong hypothesis. Heart Fail Rev 2007;12(3-4):331-43.

58. Dirkx E, da Costa Martins PA, De Windt LJ. Regulation of fetal gene expression in heart failure. Biochim Biophys Acta 2013;1832(12):2414-24.

59. Lowes BD, Minobe W, Abraham WT, Rizeq MN, Bohlmeyer TJ, Quaife RA, Roden RL, Dutcher DL, Robertson AD, Voelkel NF, Badesch DB, Groves BM, Gilbert EM, Bristow MR. Changes in gene expression in the intact human heart. Downregulation of alpha-myosin heavy chain in hypertrophied, failing ventricular myocardium. J Clin Invest 1997;100(9):2315-24.

60. Euler-Taimor G, Heger J. The complex pattern of SMAD signaling in the cardiovascular system. Cardiovasc Res 2006;69(1):15-25.

61. Argano C, Duro G, Corrao S, Di Chiara T, Nuzzo D, Colomba D, Scaglione R, Licata G. Transforming growth factor beta1 T29C gene polymorphism and hypertension: relationship with cardiovascular and renal damage. Blood Press 2008;17(4):220-6.

62. Schmierer B, Hill CS. TGFbeta-SMAD signal transduction: molecular specificity and functional flexibility. Nat Rev Mol Cell Biol 2007;8(12):970-82.

63. Heger J, Peters SC, Piper HM, Euler G. SMAD-proteins as a molecular switch from hypertrophy to apoptosis induction in adult ventricular cardiomyocytes. J Cell Physiol 2009;220(2):515-23.

64. Hang CT, Yang J, Han P, Cheng HL, Shang C, Ashley E, Zhou B, Chang CP. Chromatin regulation by Brg1 underlies heart muscle development and disease. Nature 2010;466(7302):627. 
65. Li L, Liu D, Bu D, Chen S, Wu J, Tang C, Du J, Jin H. Brg1-dependent epigenetic control of vascular smooth muscle cell proliferation by hydrogen sulfide. Biochim Biophys Acta $2013 ; \mathbf{1 8 3 3}(6): 1347-55$.

66. Newby LJ, Streets AJ, Zhao Y, Harris PC, Ward CJ, Ong AC. Identification, characterization, and localization of a novel kidney polycystin-1-polycystin-2 complex. J Biol Chem 2002;277(23):20763-73.

67. Chae SW, Cho EY, Park MS, Lee KB, Kim H, Kim U. Polycystin-1 expression in fetal, adult and autosomal dominant polycystic kidney. J Korean Med Sci 2006;21(3):425-9.

68. Thivierge C, Kurbegovic A, Couillard M, Guillaume R, Cote O, Trudel M. Overexpression of PKD1 causes polycystic kidney disease. Mol Cell Biol 2006;26(4):1538-48.

69. Ecder T, Schrier RW. Cardiovascular abnormalities in autosomal-dominant polycystic kidney disease. Nat Rev Nephrol 2009;5(4):221-8. 


\section{Figure legends}

Fig 1. Graphical representation of relative gene expression of hypertension, vascular remodeling genes. Graph showing the relative gene expression in control, left ventricular hypertrophy (LVH) and treated groups in cardiac and renal tissues of hypertension, vascular remodeling genes. Relative gene expression of (A) $A C E$, (B) PTGIS, (C) RGS5, (D) $T N F \alpha$, (E) $I G F 1$, in cardiac and renal tissues of control, $\mathrm{LVH}, \mathrm{H}_{2} \mathrm{~S}$ and $\mathrm{NO}$ treated and $\mathrm{H}_{2} \mathrm{~S}+\mathrm{NO}$ combined treated rats.

Fig 2. Graph showing the relative gene expression in control, LVH and treated groups of cardiac remodeling genes in cardiac tissue. Relative gene expression of MYH7, TGFB1, SMAD4 and $B R G 1$, in heart tissues of control, $\mathrm{LVH}, \mathrm{H}_{2} \mathrm{~S}$ and $\mathrm{NO}$ treated and $\mathrm{H}_{2} \mathrm{~S}+\mathrm{NO}$ combined treated rats.

Fig 3. Graph showing the relative gene expression of PKDI in control LVH and treated groups in renal tissue.

Fig 4. Heatmap showing the comparative relationship of gene expression among studied groups as tested in cardiac and renal tissues.

Fig 5. Therapeutic potential of gasotransmitters in left ventricular hypertrophy. Combined treatment of $\mathrm{H}_{2} \mathrm{~S}+\mathrm{NO}$ has cytoprotective effect in cardiac and renal tissues in left ventricular hypertrophy. The yellow font represents up-regulation while green font represents downregulation of the studied genes. The dotted arrow is indicative of predicted direct action. 


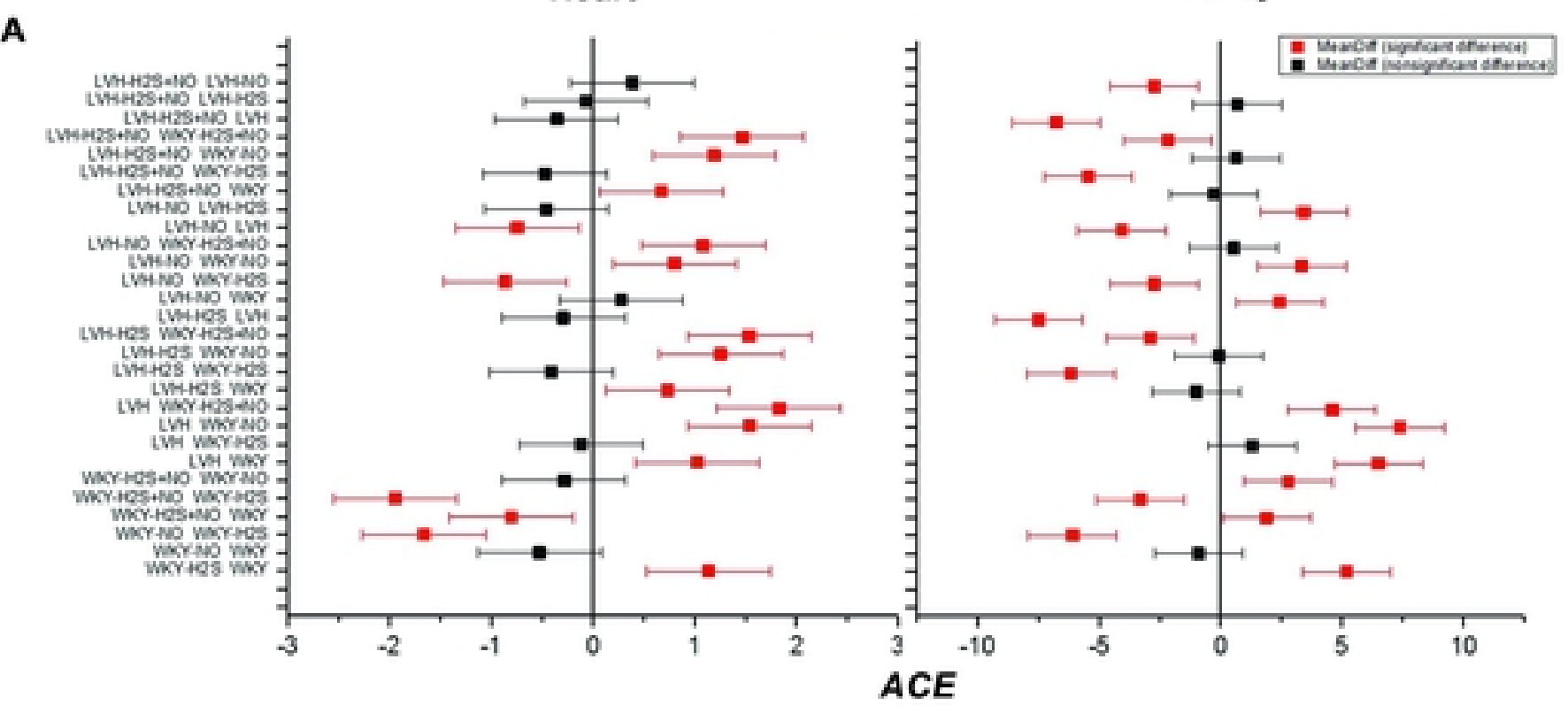

\section{B}

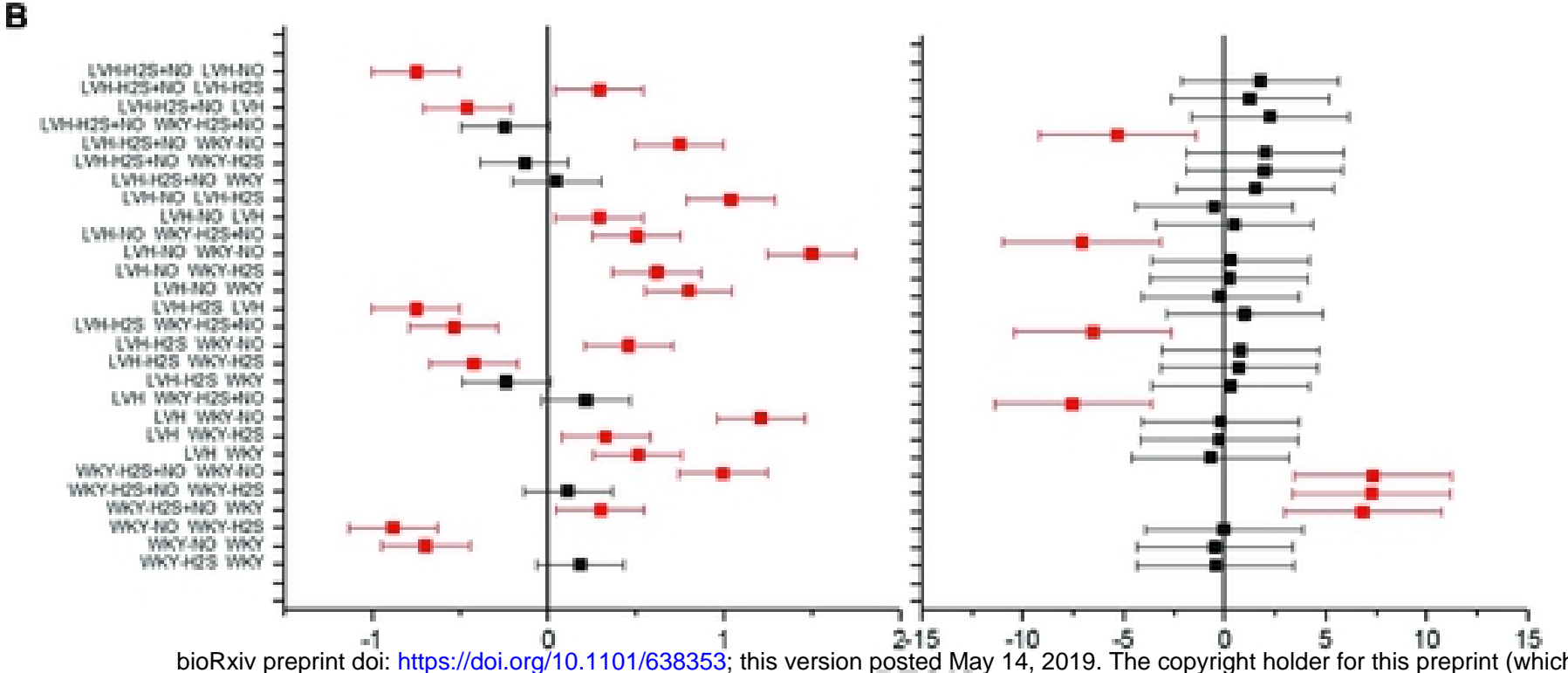

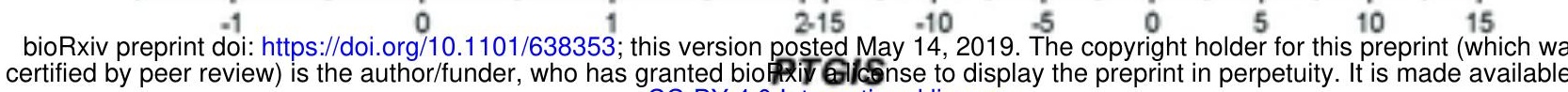
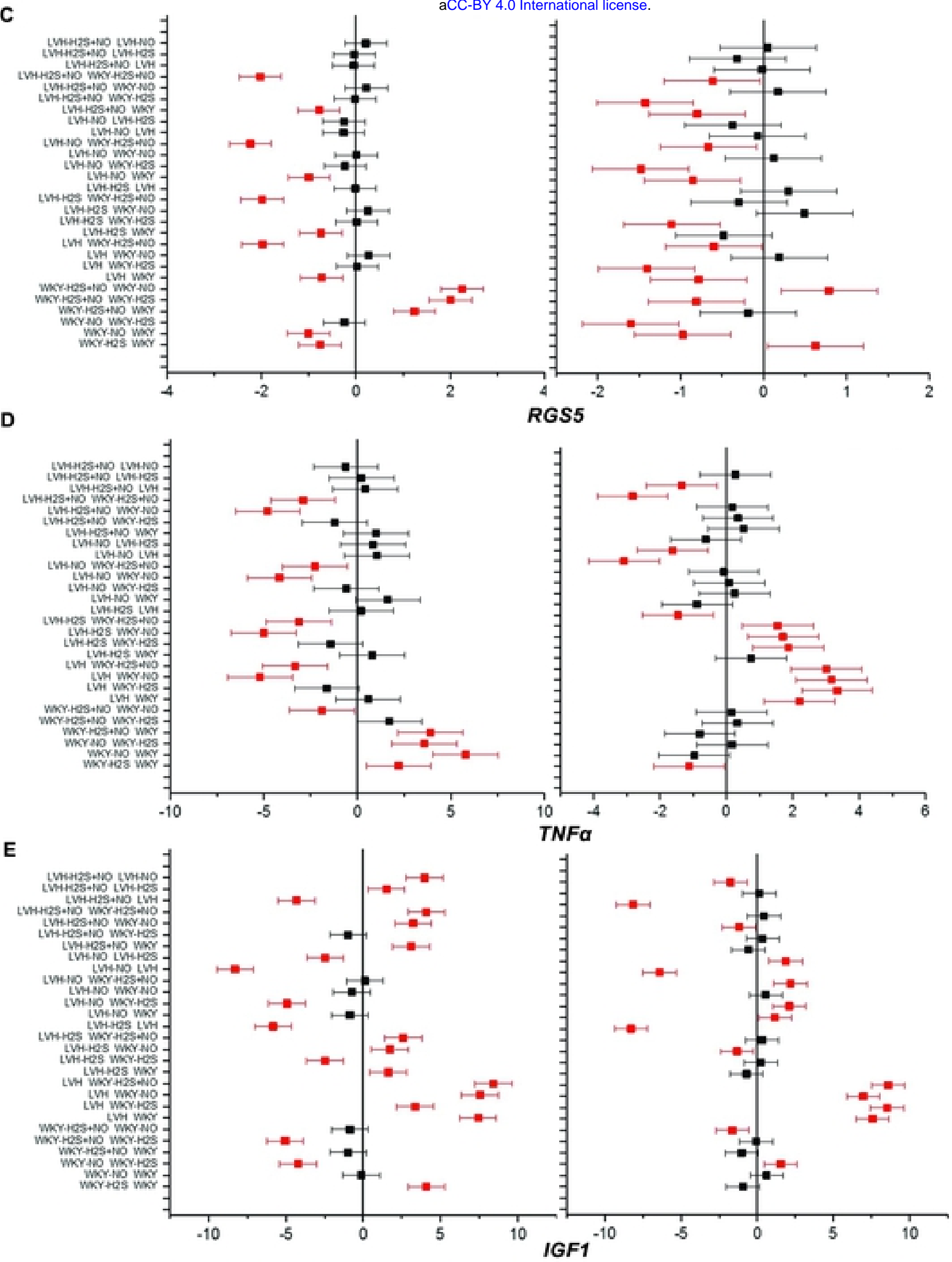

Figure 1 
bioRxiv preprint doi: https://doi.org/10.1101/638353; this version posted May 14, 2019. The copyright holder for this preprint (which was not

LVH-H2S+NO LVH-NO LVH-H2S+NO LVH-H2S

$\mathrm{LVH}-\mathrm{H} 2 \mathrm{~S}+\mathrm{NO}$ LVH $\mathrm{LVH}-\mathrm{H} 2 \mathrm{~S}+\mathrm{NO}$ WKY-H2S+NO

$\mathrm{LVH}-\mathrm{H} 2 \mathrm{~S}+\mathrm{NO}$ WKY-NO

LVH-H2S+NO WKY-H2S

LVH-H2S+NO WKY

LVH-NO LVH-H2S

LVH-NO LVH

LVH-NO WKY-H2S+NO

LVH-NO WKY-NO

LVH-NO WKY-H2S

LVH-NO WKY

LVH-H2S LVH

LVH-H2S WKY-H2S+NO

LVH-H2S WKY-NO

LVH-H2S WKY-H2S

LVH-H2S WKY

LVH WKY-H2S+NO

LVH WKY-NO

LVH WKY-H2S

LVH WKY

WKY-H2S+NO WKY-NO WKY-H2S+NO WKY-H2S WKY-H2S+NO WKY WKY-NO WKY-H2S

WKY-NO WKY

WKY-H2S WKY

CC-BY 4.0 International license.

MeanDiff (significant difference)

- MeanDiff (nonsignificant difference)
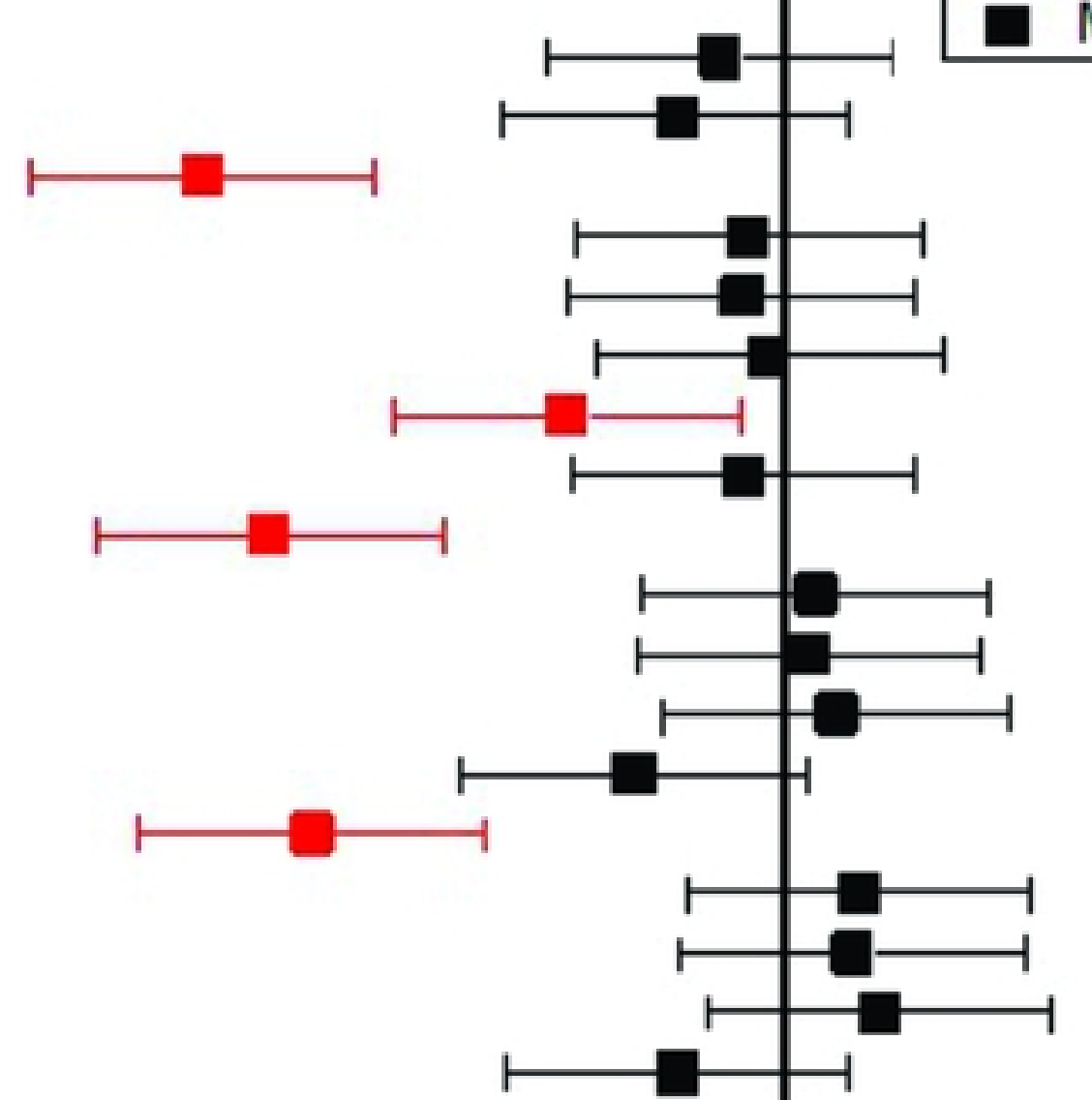

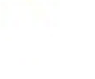
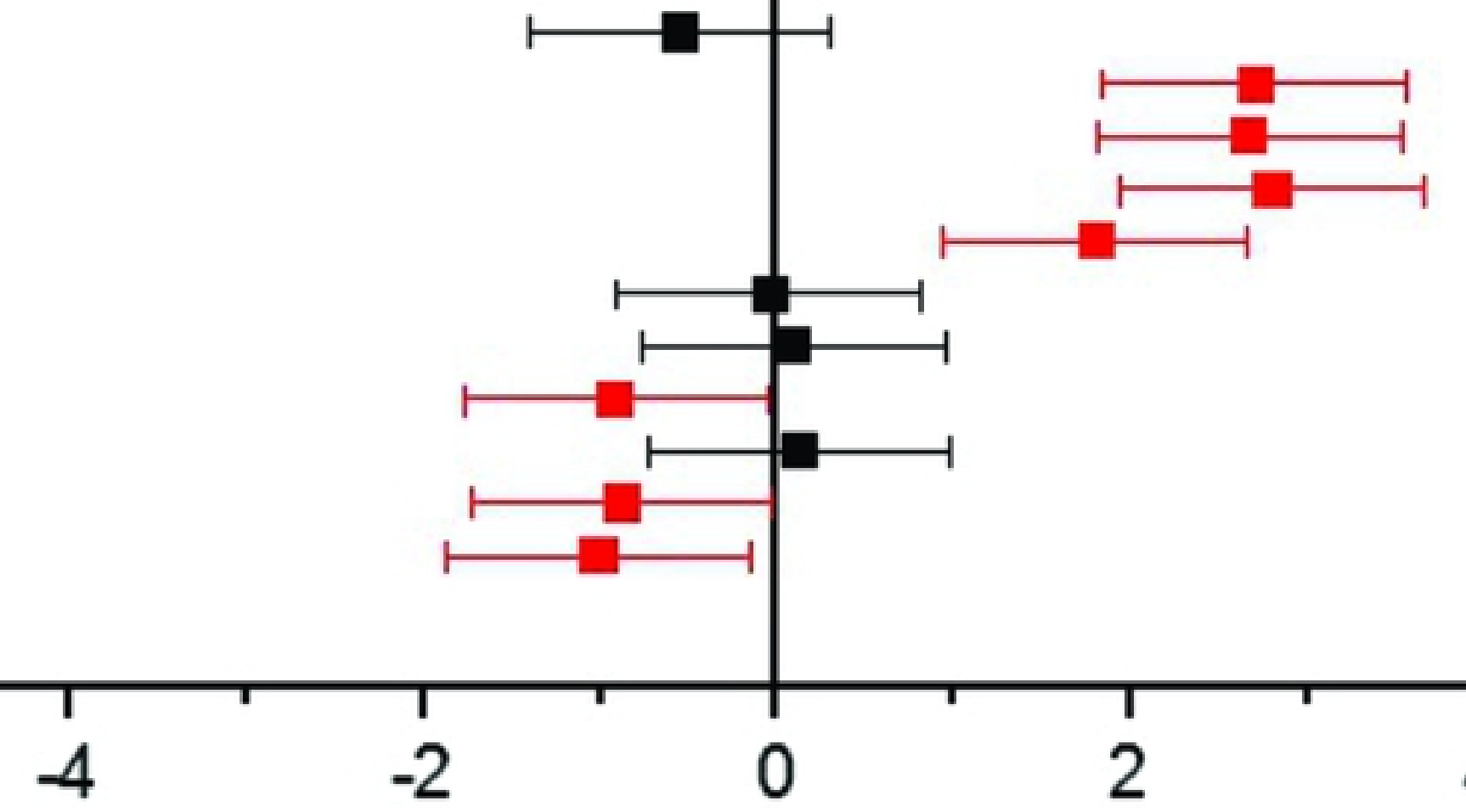

0

2

PKD1

\section{Figure 3}




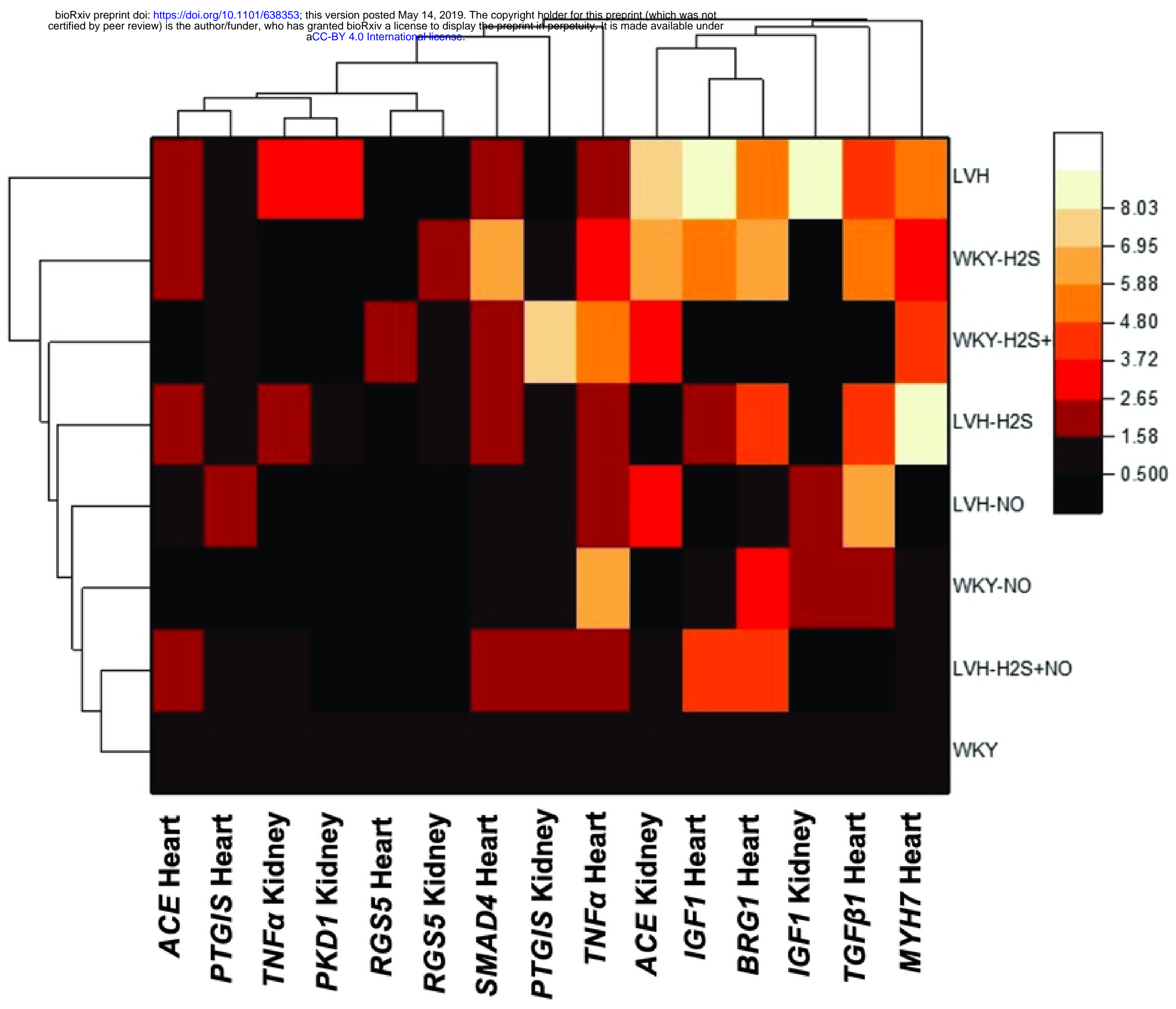

Figure 4 
